\title{
ジカルボン酸含有リン酸八カルシウムの合成と各種側鎖基の 結晶成長へ及ぼす影響
}

\author{
青木慎介 · 坂本清子* · 山口俊郎 ${ }^{* *} \cdot$ 中平 敦 \\ 京都工芸繊維大学工芸学部物質工学科，606-8585 京都市左京区松ヶ崎御所海道町 \\ *大阪産業大学教養部化学, 574-8530 大東市中垣内 3-1-1 \\ **大阪大学産業科学研究所, 567-0047 茨木市美穂ヶ丘 8-1
}

\section{Syntheses of Octacalcium Phosphate Containing Dicarboxylic Acids and Effects of the Side Groups on the Crystal Growth of Octacalcium Phosphate}

\author{
Shinsuke AOKI, Kiyoko SAKAMOTO, * Shunro YAMAGUCHI** and Atsushi NAKAHIRA \\ Kyoto Institute of Technology, Gosho-kaido-cho, Matsugasaki, Sakyo-ku, Kyoto-shi 606-8585 \\ * Osaka Sangyo University, 3-1-1, Nakagaito, Daito-shi, Osaka 574-8530 \\ **ISIR, Osaka University, 8-1, Mihogaoka, Ibaraki-shi 567-0047
}

\begin{abstract}
The syntheses of octacalcium phospates (OCPs) containing dicarboxylic acids, $\mathrm{Ca}_{8}\left(\mathrm{HPO}_{4}\right)_{2-z}\left(\mathrm{RC}_{2} \mathrm{O}_{4}\right)_{z}$ $\left(\mathrm{PO}_{4}\right)_{4} \cdot \mathrm{mH}_{2} \mathrm{O}$, were attempted. The effects of the side groups on crystal growth of these compounds were investigated. OCPs containing dicarboxylic acid were obtained from tricalcium phosphate $\left(\alpha-\mathrm{Ca}_{3}\left(\mathrm{PO}_{4}\right)_{2}\right)$ in acetic acid/sodium acetate buffer solution by hydrolysis. As for dicarboxylic acids, succinic acid, methylsuccinic acid, mercaptosuccinic acid, DL-malic acid and L-aspartic acid were used. OCPs containing dicarboxylic acid obtained in this process were determined by $\mathrm{X}$-ray diffraction, scanning electron microscope, Fourier transform infrared spectrometry, thermogravimetric analyses and chemical analyses. All of these identified compounds were structurally similar to octacalcium phosphate, $\mathrm{Ca}_{8}\left(\mathrm{HPO}_{4}\right)_{2}\left(\mathrm{PO}_{4}\right)_{4} \cdot 5 \mathrm{H}_{2} \mathrm{O}$, with expanded $a$-axis unit-cell dimensions. Phosphate ions in "hydrated layer" of OCP were replaced by succinate ions with about $94 \%$ of theoretical replacement value. The percentage of replacement for OCPs containing dicarboxylic acid having the side groups were range 24 and $59 \%$. Namely, the polarity and the size of the side groups effected on the incorporation of dicarboxylate ions into OCP interlamellar and the crystal growth.

[Received April 17, 2000; Accepted July 19, 2000]
\end{abstract}

Key-words : Octacalcium phosphate, Dicarboxylic acids, Side groups, Crystal growth, Intercalation

\section{1. 緒 言}

水酸アパタイト $\left(\mathrm{Ca}_{10}\left(\mathrm{PO}_{4}\right)_{6}(\mathrm{OH})_{2}\right.$; 以下では $\mathrm{HAp}$ と記述 $)$ に代表されるリン酸カルシウムセラミックスは生体内での歯や 骨の無機成分として重要であり，その吸着特性からこれらを充 填剤とする液体クロマトグラフィー（HAp クロマトグラ フィー) は，タンパク質や核酸などの生体高分子の分離，精製 にも利用されている1) 7). 更に触媒としてはアルコール脱水触 媒やアルコール脱水素触媒として用いられている例も報告され ている ${ }^{8,9)}$. そして, 今後これらの特性を有するリン酸カルシ ウムは環境に対して低負荷な材料としての更なる利用が期待さ れる物質である。

リン酸カルシウム類の中で $4\left[\mathrm{Ca}_{3}\left(\mathrm{PO}_{4}\right)_{2} \cdot 0.5 \mathrm{H}_{2} \mathrm{O}\right]$ 組成の 「アパタイト層」と $4\left[\mathrm{CaHPO}_{4} \cdot 2 \mathrm{H}_{2} \mathrm{O}\right]$ 組成の「水和層」との互 層構造からなるリン酸八カルシウム $\left(\mathrm{Ca}_{8}\left(\mathrm{HPO}_{4}\right)_{2}\left(\mathrm{PO}_{4}\right)_{4}\right.$. $5 \mathrm{H}_{2} \mathrm{O}$; 以下では $\mathrm{OCP}$ と記述）は他のリン酸カルシウムとは異 なり，表面だけでなくその層間空間を利用できるという構造的 特徵を有している(0),11)。この構造的特徵を活かした無機一有機 複合体化合物を合成することができれば，触媒や DDS（Drug Delivery System）等の新規な機能性材料として応用が広がる ものと考えられる.

過去の研究に扔いて Monma らは高温安定型のリン酸三カル シウム $\left(\mathrm{Ca}_{3}(\mathrm{PO})_{2}\right.$; 以下では $\alpha$-TCP と記述 $)$ を比較的温和な 条件下に打いて加水分解反応により OCP の合成に成功してお り ${ }^{12)}$ ，更にコハク酸 $\left(\mathrm{HOOC}\left(\mathrm{CH}_{2}\right)_{2} \mathrm{COOH}\right)$ をはじめとする 各種ジカルボン酸を添加することにより OCP の “水和層” 中 のリン酸イオン $\left(\mathrm{HPO}_{4}{ }^{2-}\right)$ をジカルボン酸イオン $(-\mathrm{OOC}$
$\left.\left(\mathrm{CH}_{2}\right)_{n} \mathrm{COO}-; n=1 \sim 8\right)$ で差し替え, 層間距離の異なったジ カルボン酸含有 $\mathrm{OCP}\left(\mathrm{Ca}_{8}\left(\mathrm{HPO}_{4}\right)_{2-z}\left(\mathrm{C}_{n} \mathrm{H}_{2 n} \mathrm{C}_{2} \mathrm{O}_{4}\right)_{z}\left(\mathrm{PO}_{4}\right)_{4}\right.$. $\left.m \mathrm{H}_{2} \mathrm{O}\right)$ の合成にも成功している13) 19)。 また, Marković らの 報告により OCP の $a$ 軸がスベリン酸を用いることにより最大 で約1.4倍まで拡大するということが報告されている20) 22). その他には甲殼類の殼に含まれる成分キトサンとOCP を複合 化したという報告が Viala らによってなされている23)。しか し，その層間への各物質（有機物，無機物，金属等）の取り込 みについてはいまだに不明な点が多いのが現状である.

そこで本研究では，さまざまな有機物や無機物そして金属な ぞが取り込まれた OCP 複合体の合成を行うための基礎的研究 の一環として, 今回はジカルボン酸の中でも比較的よく用いら れているコハク酸に着目し, 各種側鎖基を持つジカルボン酸含 有の OCP を合成し，更にそれらの側鎖基が結晶成長へ及ぼす 影響について検討を行った。

\section{2. 実験方法}

\section{1 試料及び試料調製}

使用した出発原料粉末は太平化学産業製の高純度 $\alpha$-TCP 粉 末（粉砕品， $\mathrm{Ca} / \mathrm{P}=1.50$ ，不純物 $<0.01 \%$ ）である. 溶媒と しては既報 ${ }^{24)}$ に基づいて作製した種々の $\mathrm{pH}$ の酢酸/酢酸ナト リウム緩衝液を用いた。添加するジカルボン酸はコハク酸 $\left(\mathrm{HOOC}\left(\mathrm{CH}_{2}\right)_{2} \mathrm{COOH}\right)$, メチルコハク酸 $\left(\mathrm{HOOCCH} \mathrm{CH}_{2}\left(\mathrm{CH}_{3}\right)\right.$ $\mathrm{COOH})$, メルカプトコハク酸 $\left(\mathrm{HOOCCH} \mathrm{H}_{2} \mathrm{CH}(\mathrm{SH}) \mathrm{COOH}\right)$, $\mathrm{DL}$ リンゴ酸（ $\left.\mathrm{HOOCCH}_{2} \mathrm{CH}(\mathrm{OH}) \mathrm{COOH}\right)$ そして $\mathrm{L}(+)$-アス パラギン酸ナトリウム一水和物 $\left(\mathrm{HOOCCH}_{2} \mathrm{CH}\left(\mathrm{NH}_{2}\right)\right.$ 
$\left.\mathrm{COONa} \cdot \mathrm{H}_{2} \mathrm{O}\right)$ を用いた．ここで $\mathrm{L}(+)$-アスパラギン酸につ いてナトリウム塩を用いたのは酢酸/酢酸ナトリウム緩衝溶液 中に溶解が困難なためである. それ以外のジカルボン酸につい ては $\mathrm{pH}$ 調整用として $1 \mathrm{~N}$-水酸化ナトリウム水溶液を所定量用 いた.

実験はまず，各種 $\mathrm{pH}$ の酢酸/酢酸ナトリウム緩衝液 $18 \mathrm{ml}$ に 5 種類のジカルボン酸（ナトリウム塩を含む）を $4.5 \mathrm{mmol}$ 添加し, コハク酸, メチルコハク酸, メルカプトコハク酸そし てDL-リンゴ酸については所定量の $1 \mathrm{~N}$-水酸化ナトリウム水 溶液を更に添加し溶解した．このとき，溶液の $\mathrm{pH}$ が $\mathrm{pH}=5$ 前後になるように調製を行った（この時点で測定した $\mathrm{pH}$ を

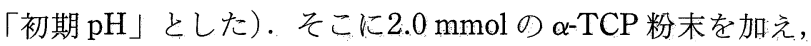
スターラーでかくはんしながら，オイルバス中で $50^{\circ} \mathrm{C}, 3 \mathrm{~h}$ の 条件で加水分解反応を行った．この反応時の $\mathrm{pH}$ ，温度，時間 については Monma らの報告を参照し決定した ${ }^{12)}$. 得られた生 成物は吸引沪過し，その沪液については $\mathrm{pH}$ の測定を行った

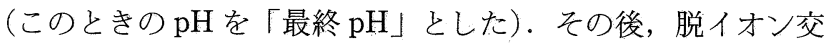
換水で 3 回洗浄し, $50^{\circ} \mathrm{C}$ に保った乾燥機中で $24 \mathrm{~h}$ 乾燥した.

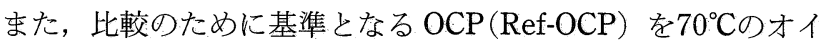
ルバス中で $\mathrm{pH}=3.3$ の酢酸/酢酸ナトリウム緩衝液中で $\alpha$-TCP の加水分解によって合成を行ったものを使用した.

\section{2 生成物のキャラクタリゼーション}

乾燥した生成粉末については, 粉末 X 線回折装置（理学電 機製，RINT-2500）で同定し，微細組織の観察については走 査型電子顕微鏡 (JEOL 製, JSM-IC845) で行った。 また，含 有されている有機成分を調べるためにフーリエ変換赤外分光装 置（日本電子製，IR-Winspec100）を用いた，更に熱重量の測 定（島津製作所製，DTG-50）を行い，炭素の含有量について は CHN マイクロアナライザー (Perkin Elmer 製) を用い, $\mathrm{Ca}$ 及び P の定量はそれぞれ全自動蛍光X線分析装置 (Philips 製, PW1480 型) を用いて測定を行った.

\section{3. 結 果}

本実験で得られた 6 種類の生成物の合成条件を表 1 に示 す.ここで, 最終 $\mathrm{pH}$ が初期 $\mathrm{pH}$ に比べて若干高い値を示して いるのは出発原料の $\alpha$-TCP が (1) 式, (2)式のような加水分解 反応によって OCP，ジカルボン酸含有 OCP それぞれに転化す る際に溶液中の水素イオンを構造中に取り込んだため, 溶液中 の水素イオン濃度が減少し, 水酸化物イオンが増加したためで あると考えられる.

$$
\begin{aligned}
& 3 \mathrm{Ca}_{3}\left(\mathrm{PO}_{4}\right)_{2}+7 \mathrm{H}_{2} \mathrm{O} \longrightarrow \mathrm{Ca}_{8}\left(\mathrm{HPO}_{4}\right)_{2}\left(\mathrm{PO}_{4}\right)_{4} \cdot 5 \mathrm{H}_{2} \mathrm{O} \\
& +\mathrm{Ca}^{2+}+2 \mathrm{OH}^{-} \\
& 3 \mathrm{Ca}_{3}\left(\mathrm{PO}_{4}\right)_{2}+z \mathrm{RC}_{2} \mathrm{O}_{4}{ }^{2-}+(m+2) \mathrm{H}_{2} \mathrm{O} \\
& \longrightarrow \mathrm{Ca}_{8}\left(\mathrm{HPO}_{4}\right)_{2-z}\left(\mathrm{RC}_{2} \mathrm{O}_{4}\right)_{z}\left(\mathrm{PO}_{4}\right)_{4} \cdot m \mathrm{H}_{2} \mathrm{O} \\
& \quad+z \mathrm{HPO}_{4}^{2-}+\mathrm{Ca}^{2+}+2 \mathrm{OH}^{-}
\end{aligned}
$$

ここで, コハク酸（ $\left.\mathrm{R}: \mathrm{C}_{2} \mathrm{H}_{4}\right)$ ， メチルコハク酸（ $\left.\mathrm{R}: \mathrm{C}_{3} \mathrm{H}_{6}\right)$, メルカプトコハク酸（R: $\left.\mathrm{C}_{2} \mathrm{H}_{4} \mathrm{~S}\right), \mathrm{DL}$-リンゴ酸（ $\left.\mathrm{R}: \mathrm{C}_{2} \mathrm{H}_{4} \mathrm{O}\right)$ そしてL-アスパラギン酸 $\left(\mathrm{R}: \mathrm{C}_{2} \mathrm{H}_{5} \mathrm{~N}\right)$ であり， $z=0 \sim 1$ であ る.

得られた生成物の X 線回折パターンを図 1，図 2 に示す. この図から，側鎖基を有するジカルボン酸含有 OCP のピーク 強度が Ref-OCP と比較して小さくなっていることが確認され たが，そのすべての第一ピークは OCP の特徵的な (100)面を 示す約 $4^{\circ}$ 付近のピークであり, $26.0^{\circ}$ にも OCP 特有のピーク が観測された. また, 各種ジカルボン酸含有 OCP の面間隔は それぞれコハク酸含有 $\mathrm{OCP}(\mathrm{Suc}-\mathrm{OCP})$ で2.17 nm $\left(2 \theta=4.10^{\circ}\right)$ ， メチルコハク酸含有 $\mathrm{OCP}(\mathrm{Met}-\mathrm{OCP})$ で $2.05 \mathrm{~nm}\left(2 \theta=4.32^{\circ}\right)$, メルカプトコハク酸（Mer-OCP)で2.10 nm $\left(2 \theta=4.23^{\circ}\right)$, DLリンゴ酸含有 $\mathrm{OCP}(\mathrm{Mal}-\mathrm{OCP})$ で $2.08 \mathrm{~nm}\left(2 \theta=4.27^{\circ}\right)$ そして $\mathrm{L}$-アスパラギン酸含有 $\mathrm{OCP}(\mathrm{Asp}-\mathrm{OCP})$ では $2.13 \mathrm{~nm}(2 \theta=$ $\left.4.17^{\circ}\right)$ であり, Ref-OCP の $1.87 \mathrm{~nm}\left(2 \theta=4.73^{\circ}\right)$ と比較して 拡大しており, 各種ジカルボン酸が層間に取り込をれたことを

\begin{tabular}{|c|c|c|c|c|c|c|}
\hline Sample name & $\begin{array}{l}\text { Starting } \\
\text { materials }\end{array}$ & Additive & Solvent1 & Solvent2 & $\begin{array}{l}\text { Initial } \\
\mathrm{pH}\end{array}$ & $\begin{array}{c}\text { Final } \\
\mathrm{pH}\end{array}$ \\
\hline Ref-OCP & $\begin{array}{c}\alpha-\mathrm{TCP} \\
2.0 \mathrm{mmol}\end{array}$ & - & $\begin{array}{c}\mathrm{AcOH} / \mathrm{AcONa} \\
\text { Buffer(pH=3.3) } \\
18 \mathrm{ml}\end{array}$ & - & 4.7 & 4.7 \\
\hline $\mathrm{Suc}^{-O C P}$ & $\begin{array}{c}\alpha-\mathrm{TCP} \\
2.0 \mathrm{mmol}\end{array}$ & $\begin{array}{c}\text { Succinic acid } \\
4.5 \mathrm{mmol}\end{array}$ & $\begin{array}{c}\mathrm{AcOH} / \mathrm{AcONa} \\
\text { Buffer }(\mathrm{pH}=5.9) \\
18 \mathrm{ml}\end{array}$ & $\begin{array}{c}1 \mathrm{~N}-\mathrm{NaOH} \\
6.0 \mathrm{ml}\end{array}$ & 5.1 & 5.6 \\
\hline Met-OCP & $\begin{array}{c}\alpha-\mathrm{TCP} \\
2.0 \mathrm{mmol}\end{array}$ & $\begin{array}{c}\text { Methylsuccinic } \\
\text { acid } \\
4.5 \mathrm{mmol}\end{array}$ & $\begin{array}{c}\mathrm{AcOH} / \mathrm{AcONa} \\
\text { Buffer }(\mathrm{pH}=5.9) \\
18 \mathrm{ml}\end{array}$ & $\begin{array}{c}1 \mathrm{~N}-\mathrm{NaOH} \\
6.75 \mathrm{ml}\end{array}$ & 5.4 & 5.8 \\
\hline Mer-OCP & $\begin{array}{c}\alpha-\mathrm{TCP} \\
2.0 \mathrm{mmol}\end{array}$ & $\begin{array}{c}\text { Mercaptosuccinic } \\
\text { acid } \\
4.5 \mathrm{mmol}\end{array}$ & $\begin{array}{c}\mathrm{AcOH} / \mathrm{AcONa} \\
\text { Buffer }(\mathrm{pH}=5.9) \\
18 \mathrm{ml}\end{array}$ & $\begin{array}{c}1 \mathrm{~N}-\mathrm{NaOH} \\
7.5 \mathrm{ml}\end{array}$ & 5.1 & 5.8 \\
\hline Mal-OCP & $\begin{array}{l}\alpha-\mathrm{TCP} \\
2.0 \mathrm{mmol}\end{array}$ & $\begin{array}{c}\text { DL-Malic } \\
\text { acid } \\
4.5 \mathrm{mmol}\end{array}$ & $\begin{array}{c}\mathrm{AcOH} / \mathrm{AcONa} \\
\text { Buffer(pH=5.9) } \\
18 \mathrm{ml}\end{array}$ & $\begin{array}{c}1 \mathrm{~N}-\mathrm{NaOH} \\
7.5 \mathrm{ml}\end{array}$ & 5.1 & 5.8 \\
\hline Asp-OCP & $\begin{array}{c}\alpha-\mathrm{TCP} \\
2.0 \mathrm{mmol}\end{array}$ & $\begin{array}{c}\text { Sodium } L(+) \text {-Aspartate } \\
\text { Monohydrate } \\
4.5 \mathrm{mmol}\end{array}$ & $\begin{array}{c}\mathrm{AcOH} / \mathrm{AcONa} \\
\text { Buffer }(\mathrm{pH}=5: 1) \\
18 \mathrm{ml}\end{array}$ & - & 5.1 & 5.8 \\
\hline
\end{tabular}
示唆しているものと考えられた.

図 3 に得られた生成物の SEM 観察の結果を示す. Ref-OCP においては約 $1 \sim 2 \mu \mathrm{m}$ 程の薄い平板状の結晶が確認された.

Table 1. Conditions of Syntheses for OCP Containing Dicarboxylic Acids 


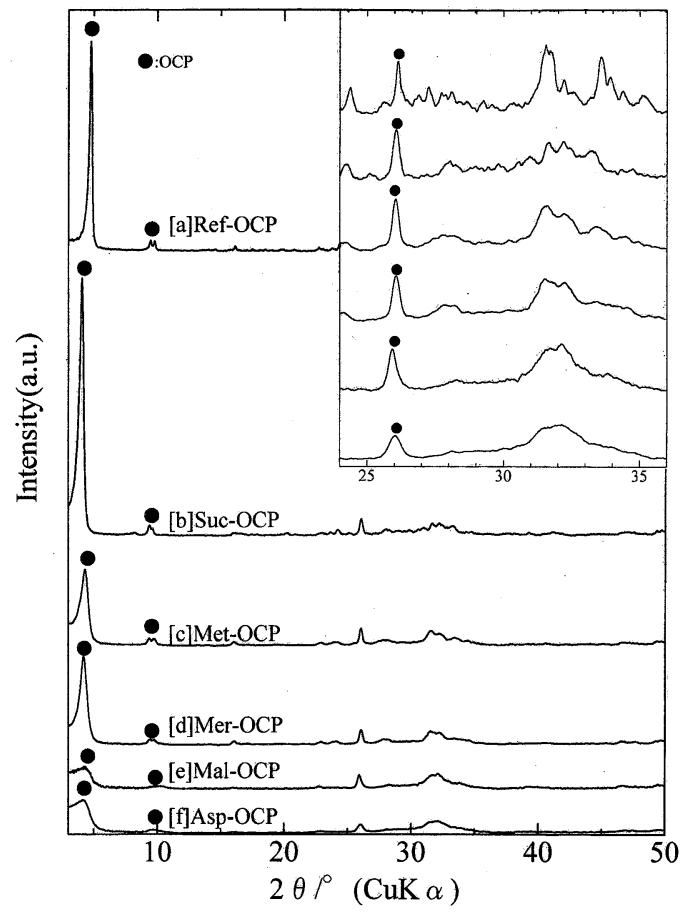

Fig. 1. XRD patterns of Ref-OCP and OCP containing dicarboxylic acids.

[a] Ref-OCP, [b] Suc-OCP, [c] Met-OCP, [d] Mer-OCP, [e] Mal$\mathrm{OCP},[\mathrm{f}]$ Asp-OCP

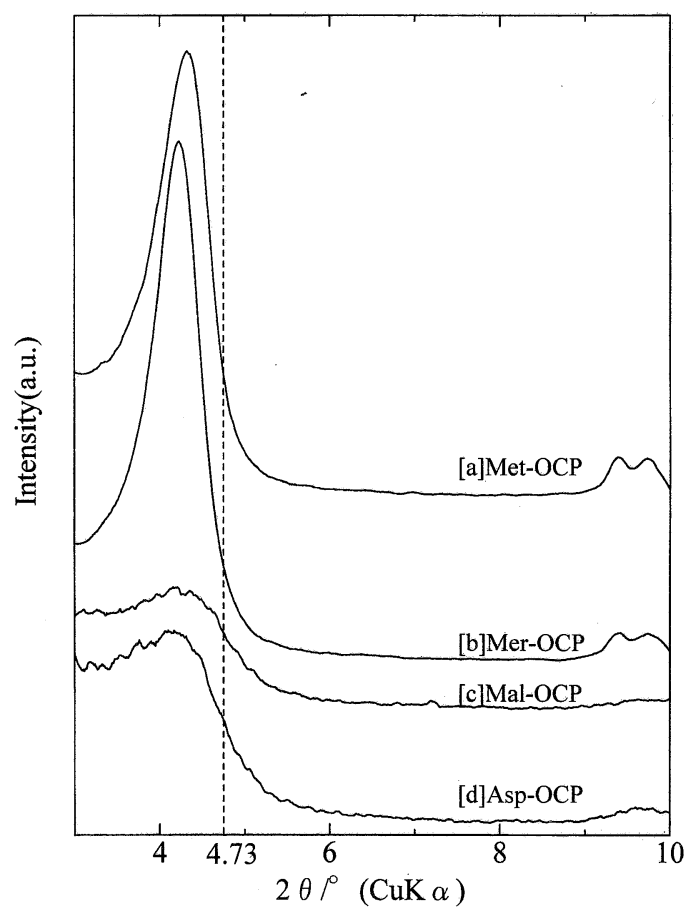

Fig. 2. XRD patterns of OCP containing dicarboxylic acids having the side groups.

[a] Met-OCP, [b] Mer-OCP, [c] Mal-OCP, [d] Asp-OCP

Suc-OCP では形状的には Ref-OCP と同様に薄い平板状の粒子 であったが，その構成粒子の大きさは $1 \mu \mathrm{m}$ 以下と小さくなっ ていた．更に Met-OCP, Mer-OCP では粒子の大きさが約 0.5 $\mu \mathrm{m}$ ほどであり, Suc-OCP と比較しても微細な粒子であった が，それらの形状は Ref-OCP, Suc-OCP 同様に薄い平板状の 粒子であった。 また，Mal-OCP 及びAsp-OCP では他のジカ ルボン酸含有 OCP で見られたような薄い平板状の粒子はほと んぞ観測されず，未発達の粒子が凝集した様子が観測された.

図 4 に FT-IR の結果を示す. OCP の特徵的なバンドとして は $863 \mathrm{~cm}^{-1}\left(\mathrm{HPO}_{4}{ }^{2-}\right.$ イオンの $\mathrm{P}-\mathrm{O}(\mathrm{H})$ の対称伸縮バンド $)$ や $910 \mathrm{~cm}^{-1}\left(\mathrm{HPO}_{4}{ }^{2-}\right.$ の強い水素結合の O-H の面内变角振動 に由来するバンド）がある. Suc-OCP において, $863 \mathrm{~cm}^{-1}$ 付 近のピークは観測されなかったが，その他の側鎖基を有するジ カルボン酸含有 OCP ではそのピークはブロードではあるが観 測された．またすべてのジカルボン酸含有 OCP において 1600 $\mathrm{cm}^{-1}$ から $1250 \mathrm{~cm}^{-1}$ にはカルボキシル基に起因するバンドが 確認され, そして $3700 \mathrm{~cm}^{-1}$ から $2800 \mathrm{~cm}^{-1}$ には $\mathrm{H}_{2} \mathrm{O}$ に起因 するバンドも観測された. 更に特徵的なものとしては, AspOCP に掠いて $1480 \mathrm{~cm}^{-1}$ 付近にアミノ基の $\mathrm{NH}_{\mathrm{z}}+$ 対称変角バ ンドが観測された。しかし，Asp-OCPにおける $3400 \mathrm{~cm}^{-1}$ か $ら 3200 \mathrm{~cm}^{-1}$ の $\mathrm{N}-\mathrm{H}$ 伸縮振動バンドや $1610 \mathrm{~cm}^{-1}$ から 1590 $\mathrm{cm}^{-1}$ の $\mathrm{NH}_{3}{ }^{+}$逆対称变角バンド及び Mer-OCPに抢ける 700 $\mathrm{cm}^{-1}$ から $600 \mathrm{~cm}^{-1}$ の C-S 伸縮吸收に起因するバンドや 2600 $\mathrm{cm}^{-1}$ から $2550 \mathrm{~cm}^{-1}$ の S-H 伸縮吸収に起因するバンドは図 4 からでは明確には確認されなかった。

表 2 に示した室温から $400^{\circ} \mathrm{C}$ まで熱重量減少の結果はそれ ぞれ, Ref-OCP, Suc-OCP, Met-OCP そして Mal-OCP では約 11〜13 mass\%であったのに対して, Asp-OCP では18.2 mass\% と他のジカルボン酸含有 OCP と比較して, 熱重量減少は大き かった。

また, 表 2 に得られた生成物の炭素含有量及び全自動蛍光 $\mathrm{X}$ 線分析装置から求めた $\mathrm{Ca} / \mathrm{P}$ の值を示す。炭素の含有量は Ref-OCP を除くジカルボン酸含有 OCP においてはSuc-OCP において 4.29 mass\%であり, 他の側鎖基を有するジカルボン 酸含有 OCP では約 2〜3 mass\%であった. Ca/Pにおいてはす ベてのジカルボン酸含有 OCP において Ref-OCP の1.34より大 きく, またジカルボン酸含有 $\mathrm{OCP}$ の組成式 $\left(\mathrm{Ca}_{8}\left(\mathrm{HPO}_{4}\right)_{2-z}\right.$ $\left.\left(\mathrm{RC}_{2} \mathrm{O}_{4}\right)_{z}\left(\mathrm{PO}_{4}\right)_{4} \cdot m \mathrm{H}_{2} \mathrm{O} ; z=0 \sim 1\right)$ 加ら推測される最大理論 $\mathrm{Ca} / \mathrm{P}(z=1)$ の 1.60 より小さい值であった.

\section{4. 考 察}

図 1, 図 2 のXRD の結果から，側鎖基を有するジカルボン 酸含有 OCP のピーク強度が Ref-OCP と比較して小さくなっ ていることが確認された. 特に Mal-OCP とAsp-OCP では非 常にブロードなピークであった. また図 3 の SEM 観察の結果 から，Ref-OCP においては約 $1 \sim 2 \mu \mathrm{m}$ の薄い板状粒子であっ たのに対して, Suc-OCP ではその大きさは約 $1 \mu \mathrm{m}$ と減少し, 更に Met-OCP p Mer-OCP においてその大きさは $1 \mu \mathrm{m}$ 以下 に減少していたが, その形状は薄い板状粒子でめった，それに 対して Mal-OCP とAsp-OCPでは薄い板状粒子はほとんど観 測されず，未発達な粒子であった。これらの理由としては $\alpha$-TCP の加水分解時に用いた各種ジカルボン酸, 特にそれぞ れ水酸基 $(-\mathrm{OH})$, アミノ基 $\left(-\mathrm{NH}_{2}\right)$ という極性がある側鎖

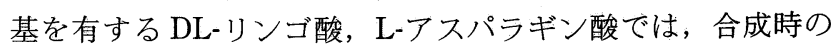
pH 5 付近においてはこれらのジカルボン酸がプラスに帯電し ている極性側鎖基とマイナスに帯電したカルボキシル基の形で 存在している.そしてそれらが二量体, 三量体の形で存在し, 更にカルシウムイオンとの結合により一種の錯体を形成してい ると推測される.そのためジカルボン酸含有 OCP 結晶の核生 成に要するカルシウムイオン濃度が減少し，その核生成が抑制 


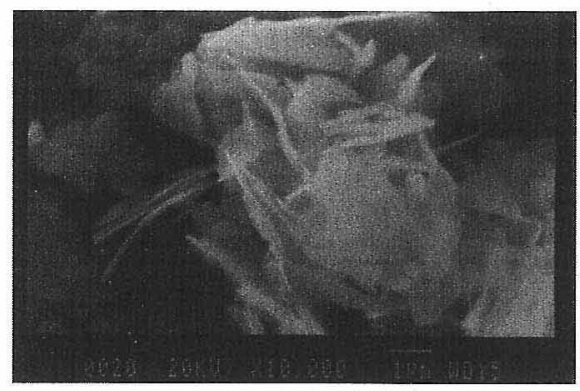

[a]Ref-OCP

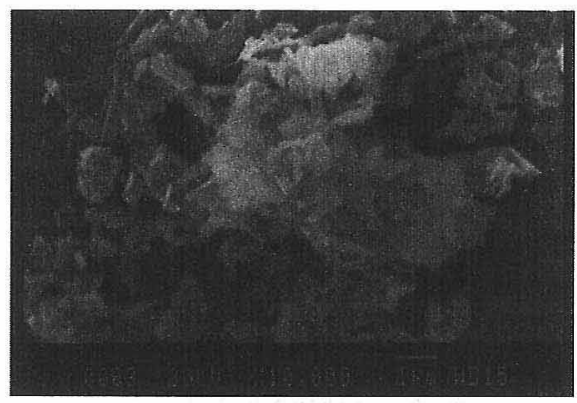

[c]Met-OCP

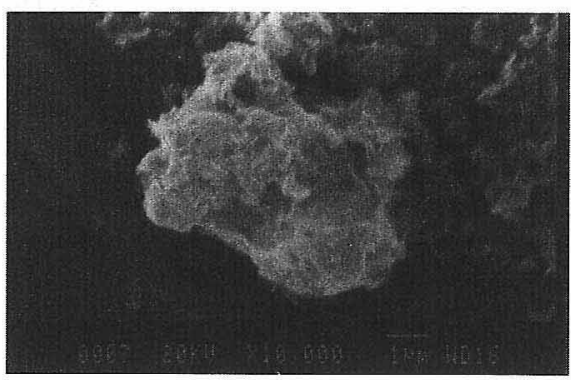

[e]Mal-OCP

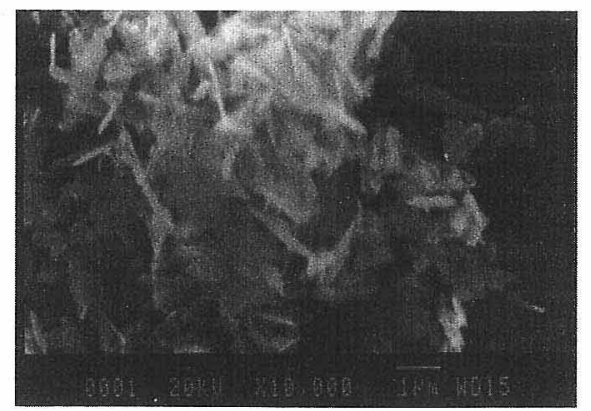

[b]Suc-OCP

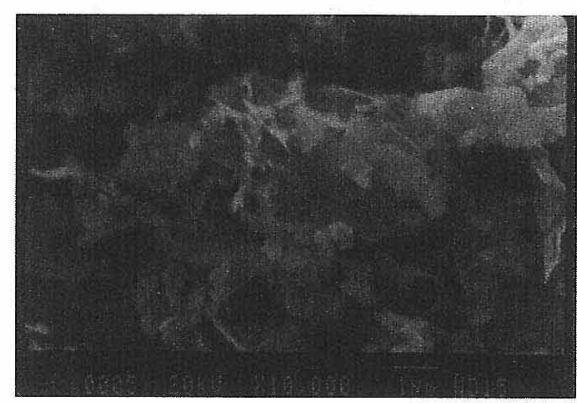

[d]Mer-OCP

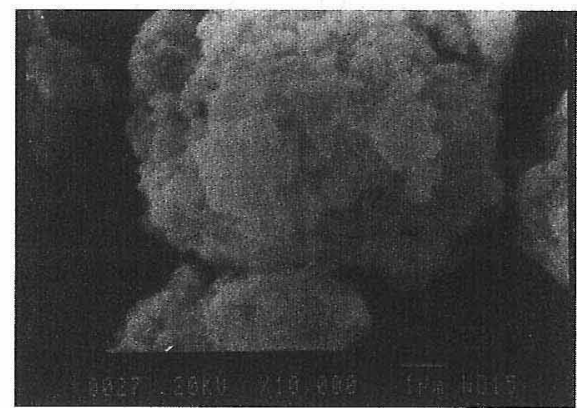

[f]Asp-OCP

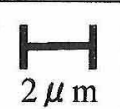

Fig. 3. Scanning electron microphotographs of Ref-OCP and OCP containing dicarboxylic acids. [a] Ref-OCP, [b] Suc-OCP, [c] Met-OCP, [d] Mer-OCP, [e] Mal-OCP, [f] Asp-OCP

される、なた，同時に結晶成長も抑制されるために Ref-OCP や側鎖基を持たないSuc-OCP と同じ反応時間において十分に 結晶成長しなかったと考えられる，そしてその結果として生成 物の結晶性の低下を引き起こしたと考えられる25),26)。しかし ながらメルカプト基 $(-\mathrm{SH})$ は極性側鎖基であるにもかかわら ず，Mer-OCP の結晶性が Mal-OCP や Asp-OCP と比べ良かっ たのは，一般にメルカプト基が水酸基やアミノ基と比較して分 子間での相互作用が弱いために DL-リンゴ酸やL-アスパラギ ン酸のように分子間同士での側鎖基とジカルボン酸のカルボキ シル基との結合が相対的に多く存在せず，その結果として結晶 成長が阻害され難かったと考えられる，また，Met-OCPにつ いては側鎖基であるメチル基 $\left(-\mathrm{CH}_{3}\right)$ がほとんど極性を持た ないために Mal-OCP や Asp-OCP と比較して結晶性が良かっ たと考えられる。しかし，極性をほとんど持たないにもかかわ らずコハク酸含有 OCP (Suc-OCP) の結晶性と比較してみると
その結晶性は低下していた．これはコハク酸が側鎖基を持つも のに比べて分子構造的観点からその構造の対称性が保たれたこ とに加光，側鎖基による立体効果の影響を受けなかったためと 考えられる.

FT-IR の結果から Suc-OCP 除いてその他の側鎖基を有す るジカルボン酸含有 OCP において $863 \mathrm{~cm}^{-1}$ 付近のピークが ブロードではあるが観測された。また，すべてのジカルボン酸 含有 OCPに打いて $1600 \mathrm{~cm}^{-1}$ から $1250 \mathrm{~cm}^{-1}$ にはカルボキシ 儿基に起因するバンドが確認されたことから，水和層内に存在 する結晶学的に異なる 2 種類の $\mathrm{HPO}_{4}{ }^{2-}$ イオンのうちアパタ イト層間を支えている支柱 $\left(\left[\mathrm{Ca}-\mathrm{HPO}_{4}-\mathrm{Ca}\right]\right)$ の $\mathrm{HPO}_{4}{ }^{2-}$ イ オンと各種ジカルボン酸イオンとの間で部分的に置換が起こっ たと考えられる. 更に Mal-OCP とAsp-OCPにおいても 910 $\mathrm{cm}^{-1}\left(\mathrm{HPO}_{4}^{2-}\right.$ の強い水素結合の $\mathrm{O}-\mathrm{H}$ の面内变角振動に由来 するバンド）の吸収バンドがブロードであるが観測されたこと 


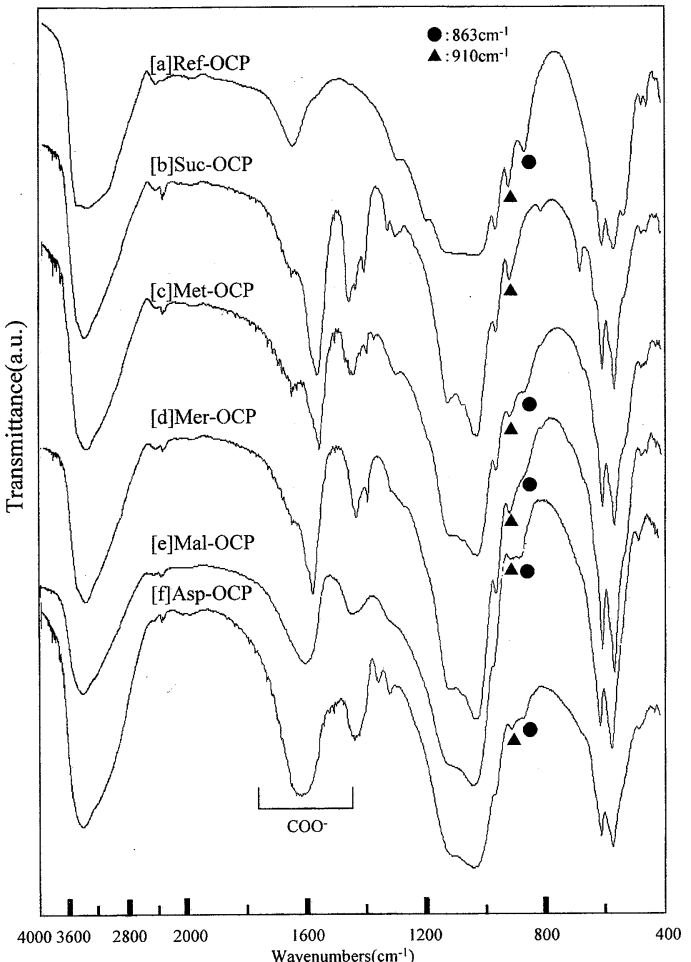

Fig. 4. FT-IR spectra of Ref-OCP and OCP containing dicarboxylic acids.

[a] Ref-OCP, [b] Suc-OCP, [c] Met-OCP, [d] Mer-OCP, [e] Mal$\mathrm{OCP},[\mathrm{f}]$ Asp-OCP

から，その構造は一部が非晶質化しながらも OCP 構造を保っ ていると考えられる。なた，Mer-OCPに関して，C-S 及び $\mathrm{S}-\mathrm{H}$ に起因するピークが確認できなかった。これは C-S 結合
では700 $\mathrm{cm}^{-1}$ から $600 \mathrm{~cm}^{-1}$ にかけての C-S 伸縮振動に起因 する吸収バンドが強度的に弱く，位置が変化することが知られ ており，また S-H 結合に関しても $2600 \mathrm{~cm}^{-1}$ から $2550 \mathrm{~cm}^{-1}$ に S-H 伸縮振動に起因する吸収バンドが特性的に弱く，更に この同じ領域においてカルボキシル基の吸収が大きいためにそ の吸収バンドが重なっている可能性が考えられる．更に MalOCP の C-O や O-H, Asp-OCP の $1480 \mathrm{~cm}^{-1}$ 付近に現れたア ミノ基の $\mathrm{NH}_{3}+$ 対称变角バンド以外の $\mathrm{C}-\mathrm{N}$ や $\mathrm{N}-\mathrm{H}$ に起因す る吸収バンドも $\mathrm{H}_{2} \mathrm{O}$ やカルボキシル基の吸収バンドと重なっ て出現しているものと考えられる.

表 2 には各種ジカルボン酸含有 OCP の見掛け上の組成を示 している. $z$ 及び $m$ は得られたジカルボン酸含有 $\mathrm{OCP}$ の組成 式を $\mathrm{Ca}_{8}\left(\mathrm{HPO}_{4}\right)_{2-z}\left(\mathrm{RC}_{2} \mathrm{O}_{4}\right)_{z}\left(\mathrm{PO}_{4}\right)_{4} \cdot m \mathrm{H}_{2} \mathrm{O}(z=0 \sim 1)$ として $\mathrm{Ca} / \mathrm{P}$ 值と熱重量減少から求めた。ここで, $m$ は $400^{\circ} \mathrm{C}$ ま゙の 熱重量減少の $85 \%$ に相当するとして見積もるというMonma の 報告を参照して計算を行った ${ }^{17)}$ 。その結果, Suc-OCPでは約 $94 \%$ O $\mathrm{HPO}_{4}^{2-}$ イオンがコハク酸イオンと交換しているのに 対して，各種側鎖基を有するコハク酸イオンでは約 $24 ５ 9 \%$ と若干低い值を示した．この結果は炭素の含有量が4.29 mass\% のSuc-OCP において他の側鎖基を有するジカルボン酸含有 OCP の約 2〜3 mass\% と比較して多いことからもその傾向を 支持しているものと考えられる，すなわち，これらの各種側鎖 基を有するジカルボン酸含有 OCP では複合化が起こりにくい ことを示している．この原因としては主に(1) 側鎖基による立 体効果，(2)側鎖基の極性による影響，の 2 点が考えられる. Markovic ら ${ }^{21)}$ により OCP 層間へはジグザグ構造を持つジカ ルボン酸を取り込みやすいと報告されていることから，(1) は 側鎖基が存在することによりその立体効果から主鎖のジグザグ 構造を取り難くさせ, 層間への取り込みが起こり難かったもの と考えられる. (2) は pH 5 付近の弱酸性においてプラスに帯 電している極性を有する側鎖基（- $\mathrm{SH},-\mathrm{OH}$ そして $\left.-\mathrm{NH}_{2}\right)$ と

Table 2. Composition of OCP and OCP Containing Dicarboxylic Acids Calculated Chemical and Thermogravimetric Analyses

\begin{tabular}{|c|c|c|c|c|}
\hline \multirow{2}{*}{$\begin{array}{l}\text { Sample } \\
\text { name }\end{array}$} & \multicolumn{2}{|c|}{ Chemical analyses } & \multirow{2}{*}{$\begin{array}{l}\text { Thermogravimetric } \\
\text { analyses }^{* 2}\end{array}$} & \multirow{2}{*}{ Compositional formula ${ }^{* 3}$} \\
\hline & Carbon $^{* 1}$ & $\mathrm{Ca} / \mathrm{P}$ ratio & & \\
\hline $\operatorname{Ref}-0 \mathrm{CP}$ & - & 1.34 & 9.5 & $\mathrm{Ca}_{8}\left(\mathrm{HPO}_{4}\right)_{2}\left(\mathrm{PO}_{4}\right)_{4} \cdot 4 \cdot 4 \mathrm{H}_{2} \mathrm{O}$ \\
\hline Suc-OCP & 4.29 & 1.58 & 11.2 & $\mathrm{Ca}_{8}\left(\mathrm{HPO}_{4}\right)_{1.06}\left(\mathrm{C}_{2} \mathrm{H}_{4} \mathrm{C}_{2} \mathrm{O}_{4}\right)_{0.94}\left(\mathrm{PO}_{4}\right)_{4} \cdot 5.3 \mathrm{H}_{2} \mathrm{O}$ \\
\hline Met-OCP & 2.16 & 1.39 & 11.3 & $\mathrm{Ca}_{8}\left(\mathrm{HPO}_{4}\right)_{1.76}\left(\mathrm{C}_{3} \mathrm{H}_{6} \mathrm{C}_{2} \mathrm{O}_{4}\right)_{0.24}\left(\mathrm{PO}_{4}\right)_{4} \cdot 5.3 \mathrm{H}_{2} \mathrm{O}$ \\
\hline Mer-OCP & 2.18 & 1.43 & 12.9 & $\mathrm{Ca}_{8}\left(\mathrm{HPO}_{4}\right)_{1.59}\left(\mathrm{C}_{2} \mathrm{H}_{4} \mathrm{SC}_{2} \mathrm{O}_{4}\right)_{0.41}\left(\mathrm{PO}_{4}\right)_{4} \cdot 6.2 \mathrm{H}_{2} \mathrm{O}$ \\
\hline Mal-OCP & 1.97 & 1. 48 & 11.3 & $\mathrm{Ca}_{8}\left(\mathrm{HPO}_{4}\right)_{1.41}\left(\mathrm{C}_{2} \mathrm{H}_{4} \mathrm{OC}_{2} \mathrm{O}_{4}\right)_{0.59}\left(\mathrm{PO}_{4}\right)_{4} \cdot 5.7 \mathrm{H}_{2} \mathrm{O}$ \\
\hline Asp-OCP & 2.59 & 1.44 & 18.2 & $\mathrm{Ca}_{8}\left(\mathrm{HPO}_{4}\right)_{1.56}\left(\mathrm{C}_{2} \mathrm{H}_{5} \mathrm{NC}_{2} \mathrm{O}_{4}\right)_{0.44}\left(\mathrm{PO}_{4}\right)_{4} \cdot 9.2 \mathrm{H}_{2} \mathrm{O}$ \\
\hline
\end{tabular}

$* 1, * 2$ All values of mass $\% * 2$ The samples were heated from R.T. to $400^{\circ} \mathrm{C}$.

$* 3$ General formula: $\mathrm{Ca}_{8}\left(\mathrm{HPO}_{4}\right)_{2-\mathrm{z}}\left(\mathrm{RC}_{2} \mathrm{O}_{4}\right)_{\mathrm{z}}\left(\mathrm{PO}_{4}\right)_{4} \cdot \mathrm{mH}_{2} \mathrm{O}(\mathrm{z}=0 \sim 1)$. 
マイナスに帯電したカルボキシル基, そしてカルシウムイオン との分子・原子間同士での相互作用のため層間への取り込みが 起こりにくくなり，更には結晶性の低下を引き起こす原因と なったものと考えられる.

以上の結果から, 本プロセスにおいて OCP 層間にジカルボ ン酸が取り込をれたジカルボン酸含有 OCP の合成に成功し, また，その側鎖基の立体効果や極性の違いにより，OCP 層間 への取り込みや結晶成長に影響を及ぼすことが明らかになっ た。

\section{5. 結 論}

本研究では, 各種側鎖基を有するコハク酸骨格のジカルボン 酸を含有させたジカルボン酸含有 OCP の合成を試み，また， 各種側鎖基の結晶成長に及ぼす影響について検討した. 各種分 析結果から総合的に解釈するとコハク酸含有 OCP では OCP 層間の約 $94 \%$ の $\mathrm{HPO}_{4}{ }^{2-}$ イオンとコハク酸イオンが置換し, 他の各種側鎖基を有するコハク酸では約 $24 ５ 9 \%$ の部分的な 置換が起こるという結果を得た。つまり，側鎖基の立体効果や その極性の違いにより OCP 層間への取り达みに影響を与えて いることが明らかになった．また側鎖基の極性はその結晶成長 にも影響を与え, その結果として粒子の結晶性の大小に変化を 起こしたものと考えられる.

\section{文献}

1) A. Tiselius, S. Hjerén and Ö. Levin, Arch. Biochem. Biophys., 65, 132-35 (1956).

2) G. Bernardi, M. G. Giro and C. Gaillard, Biochem. Biophys. Acta, 278, 409-20 (1972).

3) G. Bernardi, Methods Enzymol., 21, 95-139(1971).

4) G. Bernardi, Methods Enzymol., 27, 471-79 (1973).

5) M. Spencer and M. Grynpas, J. Chromatogr., 166, 423-34
(1978).

6) M. Spencer, J. Chromatogr., 166, 435-46 (1978).

7) K. Ohta, H. Monma and T. Kawasaki, Inorganic Materials, 6, 224-30 (1999) [in Japanese].

8) J. A. S. Bett, L. G. Christner and W. K. Hall, J. Am. Chem. Soc., 89, 5535-41 (1967).

9) C. L. Kibby, S. S. Lande and W. K. Hall, J. Am. Chem. Soc., 94, 214-20 (1971).

10) W. E. Brown, Nature, 196, 1048-50 (1962).

11) H. Monma, Gypsum \& Lime, 166, 113-21 (1980) [in Japanese].

12) H. Monma, J. Mater. Sci., 15, 2428-34 (1980).

13) H. Monma and M. Goto, Bull. Chem. Soc. Jpn., 56, 3843-44 (1983)

14) H. Monma, Bull. Chem. Soc. Jpn., 57, 599-600 (1984).

15) H. Monma, J. Mater. Sci. Lett., 4, 147-50 (1985).

16) H. Monma and Y. Moriyoshi, J. Mater. Sci. Mater. Sci.: Mater. Med., 1, 21-25 (1990).

17) H. Monma, Gypsum \& Lime, 229, 396-401 (1990) [in Japanese].

18) H. Monma and H. Nishikawa, J. Ceram. Soc. Japan, 100, 373-76 (1992).

19) H. Monma, Gypsum \& Lime, 237, 108-14 (1992) [in Japanese].

20) M. Marković, B. O. Fowler and W. E. Brown, Chem. Mater., 5, 1401-05 (1993).

21) M. Marković, B. O. Fowler and W. E. Brown, Chem. Mater., 5, 1406-16 (1993).

22) B. O. Fowler, M. Marković and W. E. Brown, Chem. Mater., 5, 1417-23 (1993).

23) S. Viala, M. Freche and J. L. Lacout, Carbohydrate Polymers, 29, 197-201 (1996).

24) D. D. Perrin and B. Dempsey, "Buffers for $\mathrm{pH}$ and Metal Ion Control," Kodansha (1981) p. 138.

25) T. Toyama, T. Yasue and Y. Arai, J. Ceram. Soc. Japan, 106 984-88 (1998) [in Japanese].

26) T. Yasue, H. Aigami and Y. Arai, Inorganic Materials, 5, 486-92 (1998) [in Japanese]. 